\title{
Slope failure in underconsolidated soft soils during the development of a port in Tianjin, China. Part 2: Analytical study
}

\author{
S. Li, Z.Q. Yue, L.G. Tham, C.F. Lee, and S.W. Yan
}

\begin{abstract}
This paper presents the analytical study of a major landslide that occurred in a newly dredged slope during port development in the city of Tianjin, northern China. The slope comprised mainly underconsolidated and submerged soft soils. The landslide consisted of a number of individual slides that occurred sequentially and extended retrogressively and laterally into the reclaimed land. The paper proposes a slope stability assessment methodology for the examination of such slope failures, with retrogressive and lateral extension into reclaimed land. Both the total and the effective stress approaches are adopted in the slope stability assessment. Eight different sets of soil shear strength parameters are used in the assessment. They were determined by using different methods in the laboratory and in the field or by back analysis. The assessment results indicate that the total stress approach, together with undrained vane strength values, gives the best result in the stability assessment of the original dredged slope and the subsequent failed slopes. The paper further examines the factors that might have caused or triggered the occurrence of the landslide. Backfilling of a thick general soil layer and a sand cushion for vacuum preloading of the hydraulic fill in the reclaimed land might have rendered the entire slope marginally stable. Lowering of the tidal level might also have had an effect in triggering the landslide. The engineering approach and results presented in this study could be useful in the design and construction of dredged slopes in underconsolidated soft soils.
\end{abstract}

Key words: land reclamation, dredge excavation, slope stability assessment, landslide investigation, marine mud, case studies.

Résumé : Cet article présente l'étude analytique d'un important glissement de terrain qui s'est produit dans un talus nouvellement dragué pour le développement du port de la Cité de Tianjin dans le nord de la Chine. Le talus comprenait principalement des sols mous sous-consolidés et submergés. Le glissement consistait en un certain nombre de glissements individuels qui se sont produits de façon séquentielle et se sont étendus rétrogressivement et latéralement dans un terrain de remblayage en mer. Cet article propose une méthodologie d'évaluation de la stabilité pour l'examen de telles ruptures de talus avec rétrogression et extension latérale dans le terrain dragué. Les approches en fonction des contraintes totales et effectives ont été adoptées pour l'évaluation de la stabilité du talus. On a utilisé huit différents ensembles de paramètres de résistance au cisaillement du sol pour l'évaluation. Ils ont été déterminés au moyen de différentes méthodes en laboratoire et sur le terrain, ou par analyse à rebours. Les résultats de l'évaluation indiquent que l'approche en contraintes totales avec les valeurs de résistance non drainée au scissomètre donne le meilleur résultat pour l'évaluation de la stabilité du talus original dragué et des talus qui ont subséquemment atteint la rupture. L'article examine par la suite les facteurs qui auraient pu causé ou déclenché le glissement de terrain. Le remblayage d'une couche épaisse d'un sol quelconque et l'ajout d'un coussin de sable pour surcharger le remblai hydraulique par la technique de vide dans le terrain réhabilité pourraient avoir rendu marginale la stabilité de tout le talus. L'abaissement du niveau de marée pourrait aussi avoir eu un effet dans le déclenchement du glissement de terrain. L'approche d'ingénieur et les résultats présentés dans cette étude pourraient être utiles dans la conception et la construction de talus dragués dans les sols mous sous-consolidés.

Mots clés : réhabilitation de terrain, excavation par dragage, évaluation de la stabilité de talus, étude de glissement de terrain, vase marine, études de cas.

[Traduit par la Rédaction]

Received 15 August 2002. Accepted 27 May 2004. Published on the NRC Research Press Web site at http://cgj.nrc.ca on 1 March 2005.

S. Li and S.W. Yan. Geotechnical Engineering Institute, Tianjin University, Tianjin, China.

Z.Q. Yue, L.G. Tham, and C.F. Lee. Department of Civil Engineering, The University of Hong Kong, Pokfulam Road, Hong Kong, China.

${ }^{1}$ Corresponding author (e-mail: yueqzq@hkucc.hku.hk). 
Fig. 1. Location of the landslide with retrogressive extension into the reclaimed land.

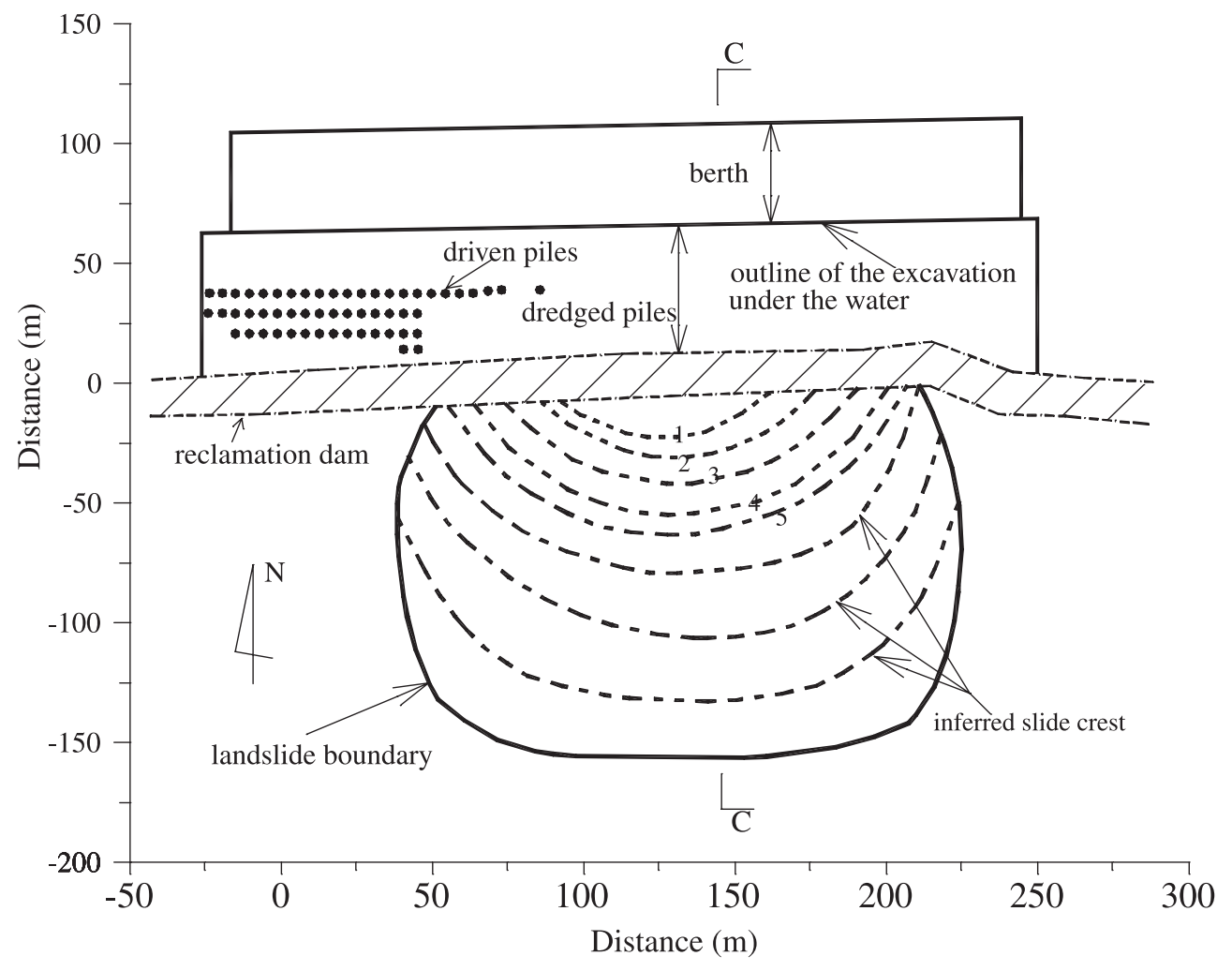

\section{Introduction}

Excavation in underconsolidated and submerged soft soils is a common practice in the creation of temporary open space for seawall or breakwater construction and of permanent open space for berths and channels (BSI 1988, 2000; CEO 2002; Hou 1987; Tsinker 1997). Large temporarily or permanently cut slopes have to be formed by dredging or other means in submerged soft soils and reclaimed land. Such cut slopes are required to be stable during the construction and operation of ports and related infrastructure projects. Cases of slope failure in underconsolidated marine mud during land reclamation and development are not uncommon (e.g., GCO 1984a; Lam and Leung 1992; Endicott 2001).

A review of the literature indicates that much work has been carried out on the assessment of slope stability problems (Bishop 1955; Morgenstern 1963; Morgenstern and Price 1965; Janbu 1977; Skempton 1977; Carson and Lajoie 1981; Lefebvre 1981; GCO 1984b; Roy and Leblanc 1988; Broms and Wong 1991; Fang and Mikroudis 1991; Lacasse 2001; Lee et al. 2001; Sheng et al. 2002; Yue and Lee 2002). Analytical methods developed for general application have also been adopted for the stability assessment of dredged slopes in underconsolidated and submerged soft soils in routine engineering practice (BSI 1988; CEO 1996; Tsinker 1997).

The stability of a cut slope can be assessed on the basis of either total or effective stresses. Lacasse (2001) pointed out that a total stress analysis may be considered for the stability assessment of slopes comprising soils such as loose sand and quick clay and that great care is needed in selecting the appropriate shear strength parameters. For soft soils, even small changes in the design parameters and methods may have significant technical and economic consequences. This is because excavation and land reclamation in soft soils for ports and related infrastructure projects are usually of large scale, costly, and time-consuming.

In a companion paper ( $\mathrm{Li}$ et al. 2005), we report the field investigation of a major landslide that occurred in dredged slopes comprising submerged and underconsolidated soft soils in Tianjin, northern China. The field investigation found that the landslide consisted of a number of individual slides that occurred sequentially and extended retrogressively and laterally into the reclaimed land (Fig. 1). This investigation also gathered a considerable amount of factual data about the landslide. These data include ground soil profile, soil physical properties, and shear strength values. In particular, six sets of the soil shear strength values were obtained from different laboratory and field tests.

In this paper, on the basis of the findings of the field investigation reported in the companion paper ( $\mathrm{Li}$ et al. 2005), we will present an analytical study of the mechanism of the landslide. In this analytical study, we will attempt to address the following pertinent problems associated the landslide:

(i) Why did the landslide consist of a number of sequential slope failures that extended retrogressively and laterally into the reclaimed land and shared a common rupture surface?

(ii) What are the most pertinent sets of soil shear strength values that were determined from different tests and methods for slope stability assessment?

(iii) What are the main factors that caused the landslide? 
Fig. 2. Soil profile along cross section $\mathrm{C}-\mathrm{C}$ in Fig. 1. Boreholes are labelled L3, M10, and M3.

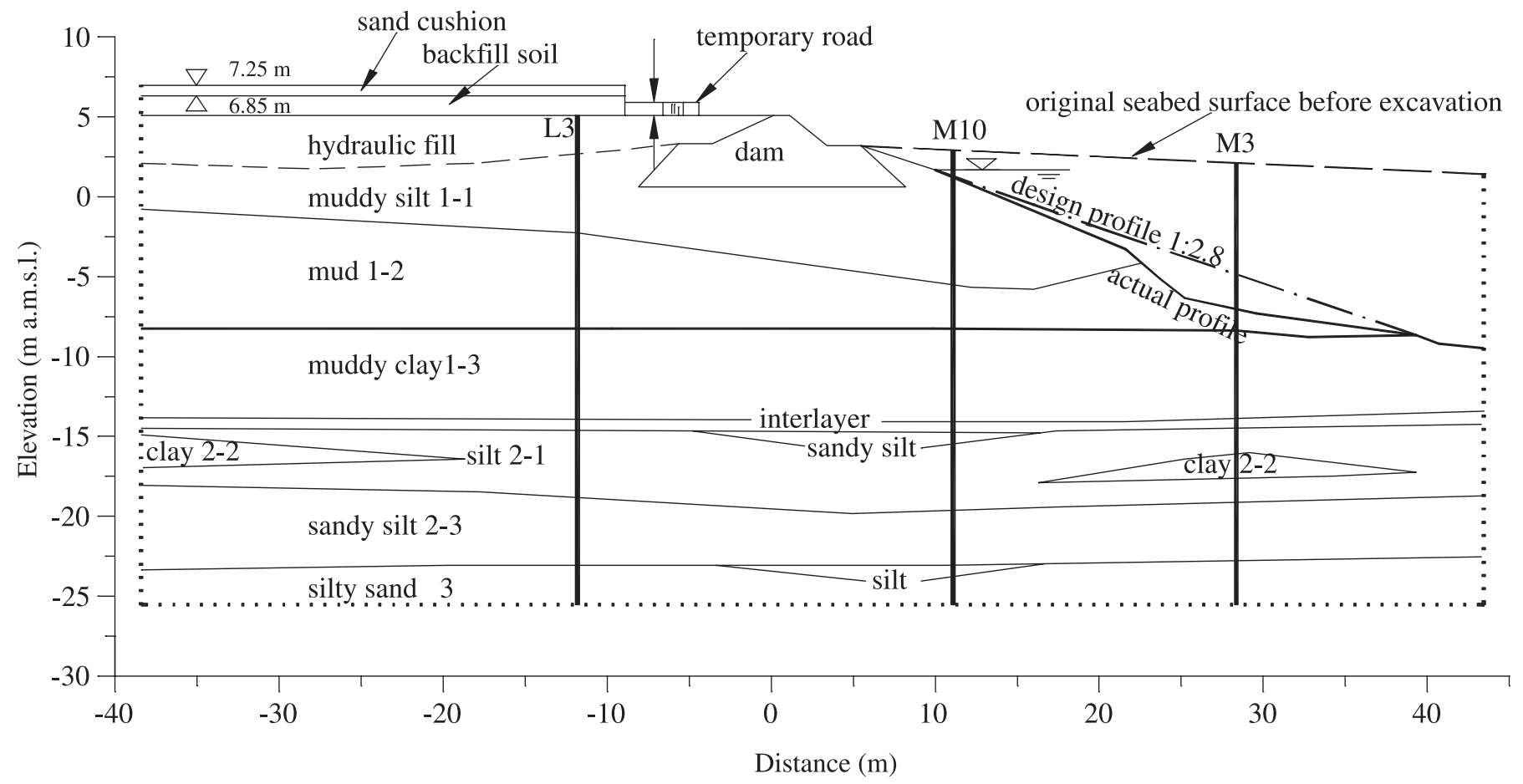

Through an in-depth study of the landslide, we developed an engineering approach to the above problems. The approach could be used for effective and accurate analysis of stability in cut slopes comprising underconsolidated and submerged soft soils.

\section{Fundamentals of theoretical investigation}

\section{Calculation method for factor of safety}

It is a routine practice to calculate the factor of safety (FOS) in the analysis of landslides and slope stability. The FOS is a mechanical indicator for assessing the degree of the risk of failure associated with a slope. It is equal to the ratio of the estimated available shear strength of a soil mass on a trial slip surface to the calculated shear stress of the soil on that surface under the given load conditions. The lower the FOS value is, the higher the risk of failure would be. Many methods are available for calculating the FOS of a slope (Huang 1983; Fang and Mikroudis 1991; Duncan 1996). A majority of the calculation methods are based on the limit equilibrium method of slices and make use of the MohrCoulomb failure criterion. The existence of many methods of slices is mainly due to the differences in assumptions used in formulating determinate equilibrium equations from the indeterminate equilibrium problem of a soil mass above an assumed slip surface (Morgenstern 1963; Morgenstern and Price 1965; Fredlund and Krahn 1977; Ching and Fredlund 1983; Huang 1983; Fang and Mikroundis 1991).

In this study, we have adopted the simplified Bishop method of slices for the FOS calculations (Bishop 1955) and have carried out the analyses using both the total stress and the effective stress principles. The Bishop method is one of the classical methods of slices. It has been used frequently by engineers in routine slope stability assessments (Fang and
Mikroudis 1991). It can accommodate complex geometries and variable soil and groundwater conditions. Furthermore, its FOS value for a given slip surface in a slope is reasonably close to those given by other methods of slices (Fredlund and Krahn 1977).

\section{Slope geological model}

In the companion paper ( $\mathrm{Li}$ et al. 2005), we established a soil profile for the dredged slope and the reclaimed land from the field investigation. On the basis of the soil profile in cross section $\mathrm{C}-\mathrm{C}$ in Fig. 2, we developed a geological model for the analysis of stability in a dredged slope comprising soft soils. The geological model is presented in Fig. 3, with the details of the soil profile given in Fig. 2. The plan location of the geological cross section is given in Fig. 1. We use this geological model as the representative geological cross section for the analytical study of the mechanism of a landslide with retrogressive extension. The origin of the horizontal distance is located at the centre of the reclamation dam.

In the geological model, the $2.45 \mathrm{~m}$ thick general soil fill and the $0.4 \mathrm{~m}$ thick sand cushion were treated as a surcharge of $50.5 \mathrm{kPa}$ on the hydraulic fill of the reclaimed land behind the dam. The temporary $1 \mathrm{~m}$ thick road is also treated as a surcharge. Such surcharge treatment may be justified by the fact that the fills were loose and might have tension cracks. The 4 year old hydraulic fill was considered part of the in situ sublayer 1-1 of the recent marine mud deposit.

Furthermore, the field investigation indicated that the reclaimed land had a shallow groundwater table at an elevation of $+4.21 \mathrm{~m}$ above mean sea level (a.m.s.l.). When the landslide occurred, it was 09:00 on 17 September 1997. At this time of the morning, the seawater level was at an elevation of $+0.99 \mathrm{~m}$ a.m.s.l. Besides, there was no piezometric obser- 


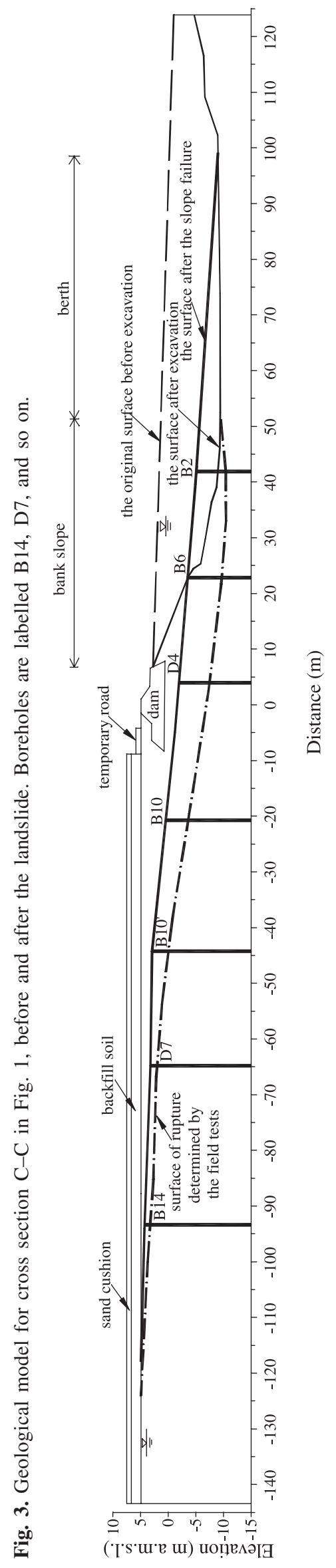

vation of the actual pore pressure levels in the in situ soil before or after the landslide. Consequently, we can determine the static groundwater table as shown in Fig. 3. This static groundwater table model does not take into account the possible presence of excess pore pressure in the in situ soft soils due to the soil fill surcharges and the original underconsolidated state.

\section{Soil shear strength values}

As discussed in the companion paper (Li et al. 2005), field and laboratory tests were conducted to determine the soil physical properties and shear strength. Table 1 summarizes the representative values of shear strength from laboratory tests carried out on soil samples obtained in the boreholes. In Table 1, the two direct shear test methods and three triaxial test methods used are the unconsolidated undrained direct (UUDD) shear test, the consolidated undrained direct (CUDD) shear test, the unconsolidated undrained (UUD) triaxial test, the consolidated undrained (CUD) triaxial test, and the consolidated drained (CD) triaxial test, respectively. The soil shear strength values thus determined were used in the assessment.

From a large number of field vane tests, we have found that the average undrained shear strength, $S_{\mathrm{u}}(\mathrm{kPa})$, can be expressed as a linear regression function of the elevation, $h$ (m):

[1] $\quad S_{\mathrm{u}}=-1.85 h+11.32$

In the FOS calculations, the marine mud was divided into a number of thin lifts to represent the depth variation of the undrained shear strength values (eq. [1]). The average value of the undrained shear strength was used for each thin lift.

Also in the FOS calculations, the total stress approach was used for each set of undrained shear strength values obtained from the three undrained tests: UUDD, UUD, and the field vane tests. The effective stress approach was adopted for each set of drained shear strength values obtained from the three consolidated tests: CUDD, CUD, and CD. In addition, we carried out a back analysis on the first slide in the dredged slope, using both the total stress and the effective stress approaches. The back analysis resulted in a set of undrained shear strength values and a set of drained shear strength values for the recent marine mud.

Approach for slope failure with retrogressive extension

Analysis of slope stability and a landslide by the limit equilibrium methods usually requires a search for the shape and location of the most critical slip surface from a large number of admissible trial slip surfaces in the slope. The most critical slip surface should have the lowest FOS value and the highest potential for a slope failure to occur along it.

Over the last three decades, a number of computer algorithms have been developed to locate the most critical slip surface in a given slope (e.g., Spencer 1973; Baker 1980; Boutrup and Lovell 1980; Huang 1983; Rahardjo and Fredlund 1984; Arai and Tagyo 1985; Nguyen 1985; Chen and Shao 1988; Zou et al. 1995; Duncan 1996; Greco 1996). The slip surfaces can be either regular or irregular in shape. In soft soils, they are usually circular. Grid search algorithms can be adopted for locating the most critical slip surfaces with circular shapes (e.g., Boutrup and Lovell 1980; 
Table 1. Representative soil shear strength values used in the FOS calculations.

\begin{tabular}{|c|c|c|c|c|c|c|c|c|c|c|c|c|}
\hline \multirow[b]{3}{*}{ Soil layer } & \multirow[b]{3}{*}{$\begin{array}{l}\text { Soil layer } \\
\text { No. }\end{array}$} & \multicolumn{4}{|c|}{ Direct shear test } & \multicolumn{6}{|c|}{ Triaxial test } & \multirow[b]{3}{*}{$\begin{array}{l}\text { Unit weight, } \\
\gamma\left(\mathrm{kN} / \mathrm{m}^{3}\right)\end{array}$} \\
\hline & & \multicolumn{2}{|c|}{ UUDD } & \multicolumn{2}{|c|}{ CUDD } & \multicolumn{2}{|c|}{ UUD } & \multicolumn{2}{|c|}{ CUD } & \multicolumn{2}{|l|}{$\mathrm{CD}$} & \\
\hline & & $\begin{array}{l}\varphi \\
\left({ }^{\circ}\right) \\
\end{array}$ & $\begin{array}{l}c \\
(\mathrm{kPa})\end{array}$ & $\begin{array}{l}\varphi^{\prime} \\
\left(^{\circ}\right)\end{array}$ & $\begin{array}{l}c^{\prime} \\
(\mathrm{kPa})\end{array}$ & $\begin{array}{l}\varphi^{\prime} \\
\left(^{\circ}\right)\end{array}$ & $\begin{array}{l}c^{\prime} \\
(\mathrm{kPa})\end{array}$ & $\begin{array}{l}\varphi^{\prime} \\
\left(^{\circ}\right)\end{array}$ & $\begin{array}{l}c^{\prime} \\
(\mathrm{kPa})\end{array}$ & $\begin{array}{l}\varphi^{\prime} \\
\left({ }^{\circ}\right)\end{array}$ & $\begin{array}{l}c^{\prime} \\
(\mathrm{kPa})\end{array}$ & \\
\hline Muddy silt & $1-1$ & 1.0 & 7.7 & 19.0 & 18.0 & 0.8 & 5.0 & 17.0 & 15.5 & 29.2 & 19.5 & 17.9 \\
\hline Mud & $1-2$ & 1.1 & 9.0 & 14.4 & 12.0 & 0.9 & 10.7 & 13.0 & 10.0 & 18.0 & 18.0 & 16.5 \\
\hline Muddy clay & $1-3$ & 2.1 & 14.2 & 16.0 & 13.0 & 1.3 & 15.8 & 16.8 & 12.0 & 26.5 & 15.5 & 17.5 \\
\hline Clay & $2-2$ & 8.4 & 28.0 & 19.5 & 23.0 & 1.8 & 33.0 & 16.5 & 37.0 & 24.0 & 31.0 & 18.7 \\
\hline Sandy silt & $2-3$ & 29.1 & 22.0 & 28.3 & 17.0 & 1.8 & 33.0 & 16.5 & 37.0 & 24.0 & 31.0 & 20.2 \\
\hline Silt sand & 3 & - & - & - & - & - & - & - & - & - & - & - \\
\hline
\end{tabular}

Note: The triaxial shear strength values for layers 1-3 and 2-3 were selected to be the same as those for layers 1-1 and 2-2, respectively. CD, consolidated drained; CUD, consolidated undrained; CUDD, consolidated undrained direct; FOS, factor of safety; UUD, unconsolidated undrained: UUDD, unconsolidated undrained direct; $\varphi$, friction angle; $c$, cohesion; $\varphi^{\prime}$, effective friction angle; $c^{\prime}$, effective cohesion.

Huang 1983; Rahardjo and Fredlund 1984; Nguyen 1985). Because a circular slip surface can be determined if its two centre coordinates and its radius are known, the search for the most critical slip surface of circular shape can be easily carried out with sufficient accuracy. However, the search for a noncircular critical slip surface has not been a routine task and is still a subject for research (Duncan 1996; Greco 1996). Furthermore, few theoretical investigations on landslides with retrogressive extension are available in the relevant literature.

It is also very important and always preferable to adopt a search technique that allows the engineer or researcher to explicitly assess the FOS calculations and make decisions on a rational basis. The field investigation found that the landslide consisted of a number of individual slides that occurred sequentially and extended retrogressively and laterally into the reclaimed land. The first slide occurred in the backfilled ground from the shoreline to about $10-20 \mathrm{~m}$ behind the reclamation dam (Fig. 1). To investigate a slope failure with retrogressive extension, we propose the following assessment approach.

We use the geological cross section $\mathrm{C}-\mathrm{C}$ in Fig. 3. For each location on the reclaimed ground surface behind the dam in cross section $\mathrm{C}-\mathrm{C}$, we examine and identify the critical slip surface with the minimum FOS value by calculating the FOS values for all admissible slip surfaces passing through that location. This location corresponds to a horizontal distance in cross section $\mathrm{C}-\mathrm{C}$. The admissible slip surfaces can pass through the rupture surface that has been confirmed by the field investigation. They can be circular or noncircular. Consequently, we can obtain the critical slip surface and its FOS value corresponding to that location.

We then shift the location forward or backward one by one and repeated the above stability calculation. We can identify the critical slip surfaces and their associated FOS values corresponding to the other locations behind the dam. Each FOS value for a critical slip surface passing through a given location on the ground surface represents the minimum risk to local slope stability. The variation of local minimum FOS values with location on the ground (or the horizontal distance to the dam centre) can explicitly show the variation of local slope stability and give a rational basis for determining the most critical slip surface of a global minimum FOS value for the entire slope. This approach can effectively take into account the different sets of shear strength values and the total and effective stress principles in the stability assessment.

Next, we assume that the soil mass above the most critical slip surface identified above is slipped down completely. The soil mass below the most critical slip surface then forms a new slope, whose slope surface is the most critical slip surface. This new slope is called remaining slope 1 . We continue to carry out the above calculations and assessment in remaining slope 1 . In the analysis, we neglect the shear resistance of the previous slide debris, as the marine mud had a very low residual shear strength value. We then identify and determine the most critical slip surface in remaining slope 1 . We then obtain remaining slope 2 . We repeat the above analysis for remaining slope 2 . We carry out such analysis until the last remaining slope becomes stable. As a result, we can obtain a number of individual slides that occur sequentially and extend retrogressively into the reclaimed land. Such theoretical results can be used to examine the mechanism of slope failure with retrogressive and lateral extension.

\section{Analysis of the slope failure with retrogressive extension}

\section{Stability of soil mass above the rupture surface}

The field investigation has shown that the slope failure with retrogressive extension had a common rupture surface (Fig. 3). This surface was covered by slipped soil mass, slide debris, and seawater. It is therefore prudent to assess the stability of the soil mass above the rupture surface.

Table 2 shows the FOS values for the soil mass above the rupture surface, in association with the original dredged slope and the remaining slopes $1-4$ along cross section $\mathrm{C}-\mathrm{C}$. The definitions of the remaining slopes 1-4 are given in Figs. 5-8, respectively. They will be examined in detail, below. The total stress approach and the effective stress approach were used in FOS calculations using the undrained and drained shear strength values, respectively. 
Table 2. FOS for the soil mass above the rupture surface in the original dredged slope and remaining slopes after the retrogressive slides.

\begin{tabular}{|c|c|c|c|c|c|c|}
\hline \multirow[b]{3}{*}{ Slope condition } & \multicolumn{6}{|c|}{ FOS with six sets of shear strength values } \\
\hline & \multicolumn{3}{|c|}{ Effective stress approach } & \multicolumn{3}{|c|}{ Total stress approach } \\
\hline & $\mathrm{CD}$ & CUDD & CUD & Vane & UUD & UUDD \\
\hline Original slope & 5.74 & 3.98 & 3.71 & 2.24 & 1.42 & 1.41 \\
\hline Remaining slope 1 & 6.57 & 4.31 & 4.14 & 1.87 & 1.48 & 1.51 \\
\hline Remaining slope 2 & 8.07 & 5.45 & 5.11 & 1.97 & 1.64 & 1.75 \\
\hline Remaining slope 3 & 9.65 & 6.55 & 6.18 & 2.20 & 1.78 & 1.98 \\
\hline Remaining slope 4 & 10.58 & 8.12 & 7.00 & 2.74 & 2.03 & 2.26 \\
\hline
\end{tabular}

Note: CD, consolidated drained; CUD, consolidated undrained; CUDD, consolidated undrained direct; FOS, factor of safety; UUD, unconsolidated undrained; UUDD, unconsolidated undrained direct.

From the results, it is evident that the FOS values for the entire landslide mass slipping on the rupture surface were $>1.4$ for the six sets of the soil shear strength values. This stability assessment result may indicate that the soil mass above the rupture surface could not fail as a single slip body.

\section{Analysis of the first slide}

We applied the assessment approach discussed above to the original dredged slope. We obtained the critical slip surfaces and the local minimum FOS values for the reclaimed ground along cross section $\mathrm{C}-\mathrm{C}$. It was found that the total and effective stress approaches and the different sets of soil shear strength values could result in different values of local minimum FOS associated with different critical slip surfaces. Further evaluation of the results indicates that their effects on the critical slip surfaces are not significant.

We summarized some of the results in Fig. 4. Figure $4 a$ illustrates the critical slip surfaces determined by the total stress approach in association with the field vane shear strength. Figure $4 b$ summarizes the variation of the local minimum FOS values of the critical slip surfaces with the horizontal distance behind the dam, for the eight sets of soil shear strength values. The corresponding FOS values are also presented in Table 3. From those results, we have the following important observations:

(i) From the dam centre to a horizontal distance of $15 \mathrm{~m}$ toward the reclaimed land, the local minimum FOS value for each shear strength set decreases quickly as the distance increases.

(ii) Beyond a horizontal distance of $20 \mathrm{~m}$ from the dam centre, the local minimum FOS value for each shear strength set increases gradually as the distance increases.

(iii) Between the horizontal distances of 15 and $20 \mathrm{~m}$ from the dam centre, the local minimum FOS value for each shear strength set changes slightly and monotonically.

(iv) The local minimum FOS value for each shear strength set has its global minimum at a horizontal distance of between 15 and $20 \mathrm{~m}$ from the dam centre.

(v) The local minimum FOS values obtained with the effective stress approach are generally greater than those obtained with the total stress approach.

(vi) The local minimum FOS values increase monotonically with the shear strength sets, in the following increasing order: UUD, UUDD, field vane, CUD, CUDD, and CD. (vii) The local minimum FOS values for the UUD and UUDD tests are always close to each other and less than that for the undrained shear strength (field vane) test in the total stress approach at each horizontal distance.

(viii) The local minimum FOS values for the CUD and CUDD tests are always close to each other and less than that for the CD test in the effective stress approach at each horizontal distance.

(ix) The effective stress approach (CD, CUDD, and CUD) results in local minimum FOS values that are greater than unity. Their global minimum value is estimated to be 1.42. In addition, the local minimum FOS values calculated using CUDD and CUD shear strength values are always close to each other.

(x) The total stress approach (UUDD, UUD, and field vane) results in local minimum FOS values of less than unity for numerous critical slip surfaces located at a horizontal distance of between $10 \mathrm{~m}$ and $70 \mathrm{~m}$ behind the dam centre. Their global minimum value is estimated to be 0.58 . In addition, the local minimum FOS values calculated using undrained shear strength values from the UUDD and UUD tests are also always close to each other.

From the above observations, we have the following key findings:

(i) For both the total and effective stress approaches and for all six sets of shear strength values used, the critical slip surface with the global minimum FOS values passes through the reclaimed ground surface at a horizontal distance of between 15 and $20 \mathrm{~m}$ behind the dam centre. This was the weakest zone, and it eventually formed the slip surface for the first slide. This location is also consistent with witness observations of the location of the first slide.

(ii) The effective stress approach resulted in FOS values that are much greater than unity. This indicates that the effective shear strength values determined from the CUDD, CUD, and CD tests are much greater than the in situ effective shear strength values of the underconsolidated soils. In other words, the consolidation process in the laboratory might have significantly strengthened the underconsolidated soft soils.

(iii) Because the newly dredged slope was stable between 13 August and 16 September 1997, before it failed on 17 September 1997, the dredged slope could have been 


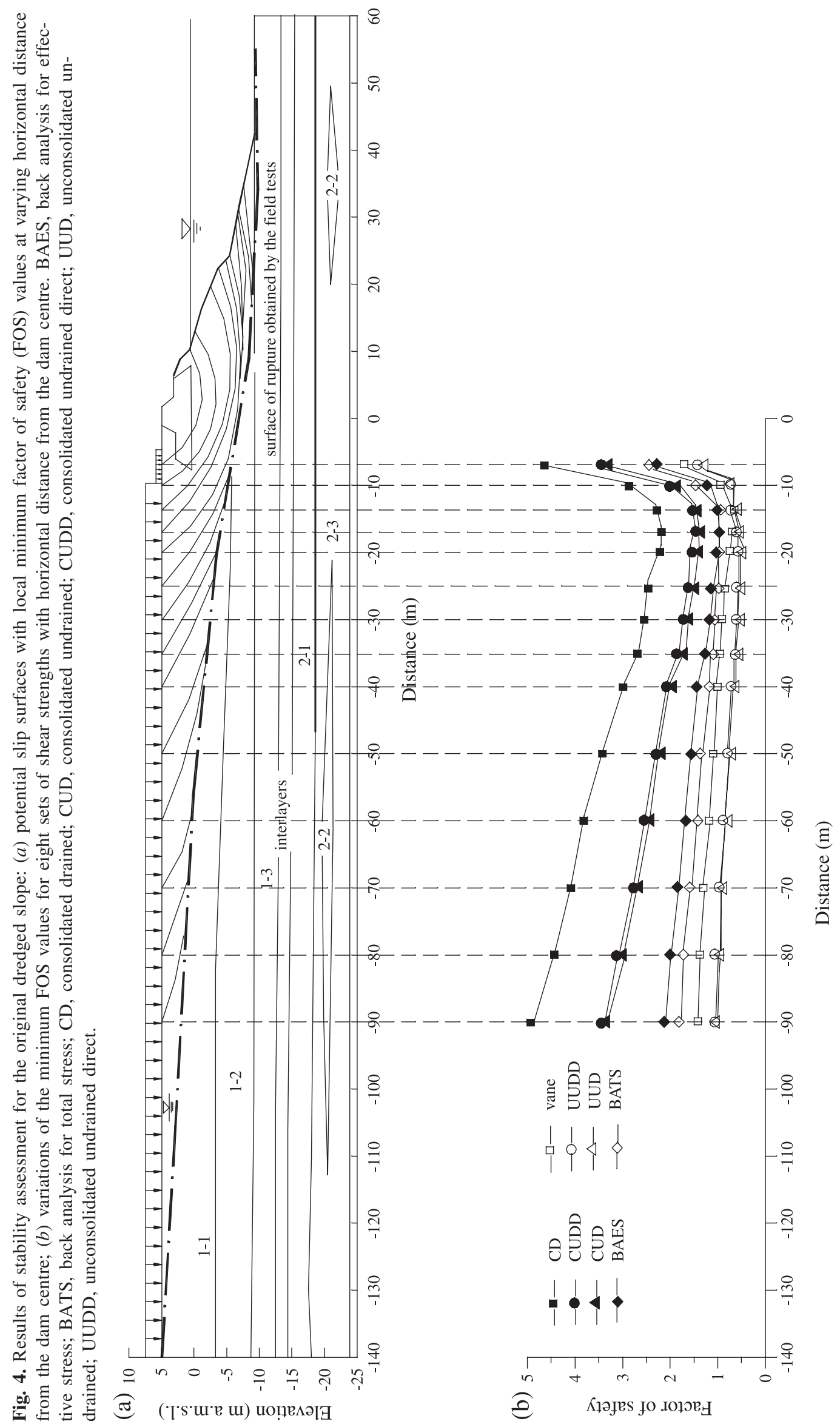


Table 3. Minimum FOS for local critical slip surfaces with varying horizontal distance from the dam centre, for the original dredged slope.

\begin{tabular}{|c|c|c|c|c|c|c|c|c|}
\hline \multirow{3}{*}{$\begin{array}{l}\text { Horizontal distance } \\
\text { from dam centre }(\mathrm{m})\end{array}$} & \multicolumn{8}{|c|}{ Minimum FOS with eight sets of shear strength values } \\
\hline & \multicolumn{4}{|c|}{ Effective stress approach } & \multicolumn{4}{|c|}{ Total stress approach } \\
\hline & $\mathrm{CD}$ & CUDD & CUD & BAES & UUD & UUDD & Vane & BATS \\
\hline 7.5 & 4.61 & 3.43 & 3.35 & 2.30 & 1.33 & 1.46 & 1.72 & 2.43 \\
\hline 10 & 2.87 & 2.00 & 1.86 & 1.26 & 0.74 & 0.78 & 0.94 & 1.45 \\
\hline 13.5 & 2.33 & 1.55 & 1.49 & 1.03 & 0.71 & 0.69 & 0.78 & 1.07 \\
\hline 16.3 & 2.19 & 1.47 & 1.42 & 1.00 & 0.64 & 0.63 & 0.76 & 1.00 \\
\hline 20 & 2.25 & 1.53 & 1.46 & 1.01 & 0.58 & 0.60 & 0.80 & 1.01 \\
\hline 25 & 2.49 & 1.64 & 1.55 & 1.12 & 0.61 & 0.58 & 0.90 & 1.06 \\
\hline 30 & 2.57 & 1.73 & 1.63 & 1.20 & 0.63 & 0.60 & 0.96 & 1.08 \\
\hline 35 & 2.70 & 1.86 & 1.72 & 1.30 & 0.64 & 0.64 & 1.01 & 1.14 \\
\hline 40 & 3.00 & 2.08 & 2.03 & 1.46 & 0.74 & 0.72 & 1.08 & 1.24 \\
\hline 50 & 3.42 & 2.31 & 2.25 & 1.56 & 0.82 & 0.81 & 1.12 & 1.37 \\
\hline 60 & 3.82 & 2.54 & 2.46 & 1.70 & 0.89 & 0.89 & 1.22 & 1.50 \\
\hline 70 & 4.09 & 2.76 & 2.69 & 1.85 & 0.98 & 0.98 & 1.34 & 1.60 \\
\hline 80 & 4.42 & 3.10 & 3.00 & 1.98 & 1.01 & 1.03 & 1.39 & 1.74 \\
\hline 90 & 4.91 & 3.38 & 3.34 & 2.14 & 1.05 & 1.07 & 1.47 & 1.84 \\
\hline
\end{tabular}

Note: CD, consolidated drained; BAES, back analysis for effective stress; BATS, back analysis for total stress; CUD, consolidated undrained; CUDD, consolidated undrained direct; FOS, factor of safety; UUD, unconsolidated undrained; UUDD, unconsolidated undrained direct.

marginally stable. Its FOS value should be close to, but somewhat less than, unity at the time of failure. In this regard, the total stress approach in association with the in situ undrained strength values (field vane) gives the best prediction of the first slide in terms of the global minimum FOS value (0.76) and the slide location. This global minimum FOS value may be considered the critical value for the slope to fail.

\section{Back analysis of the first slide}

Using both the total stress and the effective stress approaches discussed above, we carried out a back analysis for the first slide. At first, we back-calculated the total or effective shear strength values of the dredged slope soils to satisfy the condition that the global FOS value should be equal to unity. We then used the back-calculated total or effective shear strength values to assess the local minimum FOS value for all admissible slip surfaces passing through the reclaimed ground behind the dam. For simplicity, we assumed that the recent marine mud in the dredged slope was homogeneous and could be represented by one set of the shear strength values in the back analysis. From such a back analysis, we found the following results: the representative undrained shear strength of the recent marine mud, $S_{\mathrm{u}}$, is $24 \mathrm{kPa}$; and the representative parameters for effective shear strength of the recent marine mud are given by $c^{\prime}=13^{\circ}$ and $\varphi^{\prime}=10 \mathrm{kPa}$.

By comparing the back-calculated representative shear strength values with those in Table 1 and eq. [1], we can make the following observations:

(i) The representative undrained shear strength value of $S_{\mathrm{u}}=24 \mathrm{kPa}$ is between the maximum and minimum values of the field vane strength values for the original marine mud. It is in fact closer to the upper limit. (ii) The representative effective shear strength parameters of $c^{\prime}=13^{\circ}$ and $\varphi^{\prime}=10 \mathrm{kPa}$ are generally (and sometimes slightly) lower than those measured in the laboratory tests with soil consolidation.

The variations of local minimum FOS values with horizontal distance from the dam centre are plotted in Fig. $4 b$. They are given in the figure as either the back analysis for the effective stress approach (BAES) or the back analysis for the total stress approach (BATS). The exact FOS values are also summarized in Table 3. It should be noted that BAES values represent the back analysis of effective soil shear strength, and BATS values represent the back analysis of the total soil shear strength. It can be observed that the local minimum FOS values for BAES and BATS are always close to each other. The variations of the local minimum FOS values for both BAES and BATS with distance from the dam centre also clearly indicate that the critical slip surfaces with global minimum FOS values are located at a horizontal distance of between 15 and $20 \mathrm{~m}$ from the dam centre.

\section{Analysis of the second slide}

To examine slope failure with retrogressive extension into the reclaimed land, we consider that the first slide should have occurred along the critical slip surface associated with the global minimum FOS value. This critical slip surface is assumed to be the one determined by using the total stress approach in association with undrained shear strength values from the field vane tests. The horizontal distance of such a critical slip surface is estimated to be $16.3 \mathrm{~m}$ from the dam centre. In other words, the back-scar crest after the first slide is located at $16.3 \mathrm{~m}$ from the dam centre. We then redefine the remaining slope surface by incorporating this slip surface into the existing ground surface. Figure $5 a$ shows the shape 


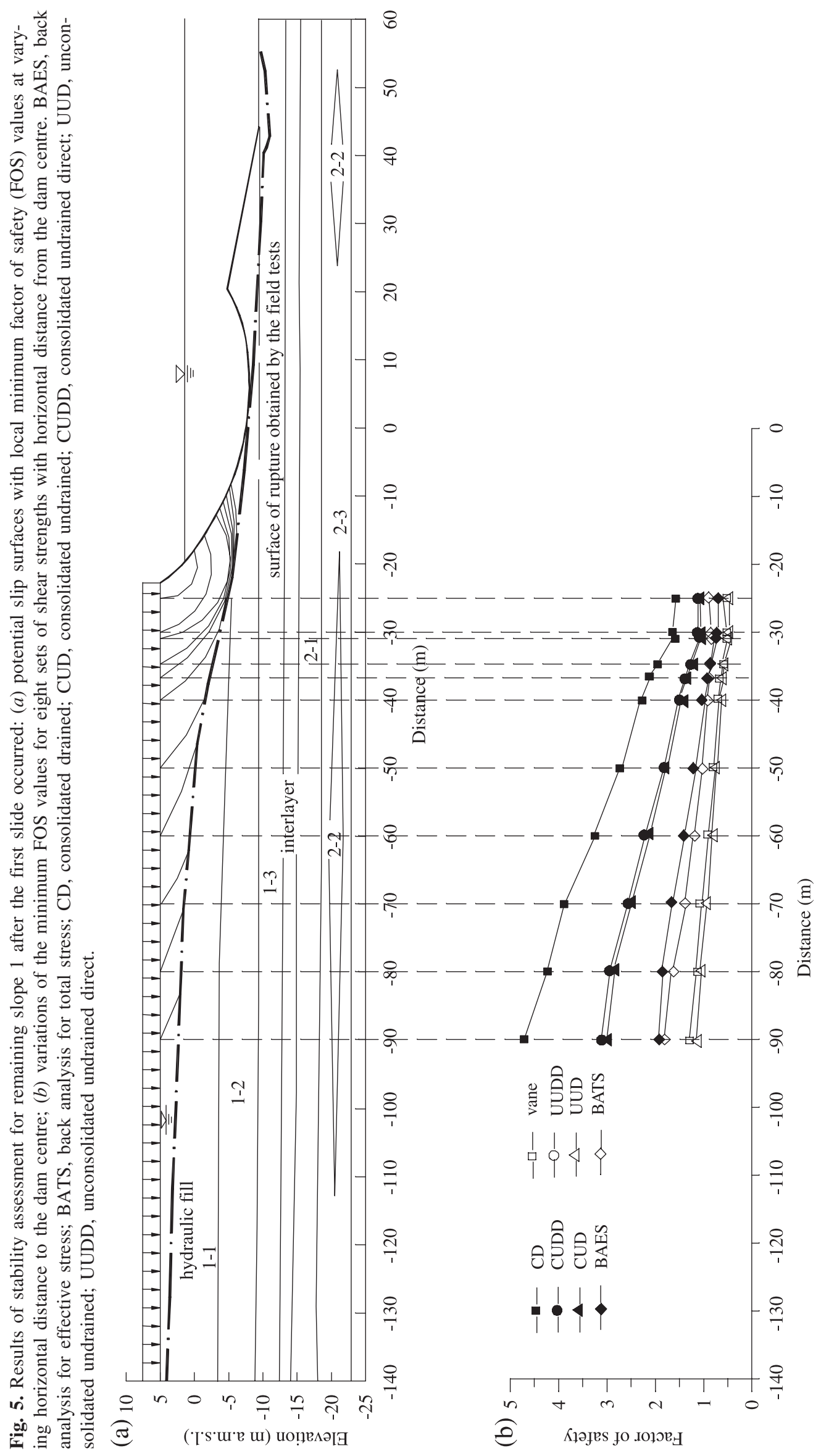


Table 4. Minimum FOS for local critical slip surfaces with varying horizontal distance from the dam centre, for remaining slope 1 after the first slide.

\begin{tabular}{|c|c|c|c|c|c|c|c|c|}
\hline \multirow{3}{*}{$\begin{array}{l}\text { Horizontal distance } \\
\text { from dam centre }(\mathrm{m})\end{array}$} & \multicolumn{8}{|c|}{ Minimum FOS with eight sets of shear strength values } \\
\hline & \multicolumn{4}{|c|}{ Effective stress approach } & \multicolumn{4}{|c|}{ Total stress approach } \\
\hline & $\mathrm{CD}$ & CUDD & CUD & BAES & UUD & UUDD & Vane & BATS \\
\hline 25 & 1.59 & 1.12 & 1.06 & 0.70 & 0.46 & 0.44 & 0.54 & 0.87 \\
\hline 30 & 1.60 & 1.08 & 1.05 & 0.70 & 0.46 & 0.45 & 0.53 & 0.81 \\
\hline 31 & 1.59 & 1.05 & 1.04 & 0.68 & 0.47 & 0.45 & 0.53 & 0.74 \\
\hline 35 & 1.92 & 1.25 & 1.24 & 0.82 & 0.54 & 0.54 & 0.58 & 0.83 \\
\hline 37 & 2.12 & 1.38 & 1.38 & 0.89 & 0.59 & 0.58 & 0.64 & 0.88 \\
\hline 40 & 2.26 & 1.48 & 1.46 & 0.95 & 0.61 & 0.62 & 0.66 & 0.92 \\
\hline 50 & 2.73 & 1.79 & 1.76 & 1.16 & 0.69 & 0.71 & 0.75 & 1.03 \\
\hline 60 & 3.25 & 2.15 & 2.10 & 1.38 & 0.82 & 0.82 & 0.88 & 1.20 \\
\hline 70 & 3.90 & 2.53 & 2.48 & 1.61 & 0.92 & 0.93 & 0.96 & 1.39 \\
\hline 80 & 4.25 & 2.93 & 2.82 & 1.84 & 1.03 & 1.04 & 1.14 & 1.62 \\
\hline 90 & 4.72 & 3.11 & 3.01 & 1.92 & 1.1 & 1.11 & 1.24 & 1.79 \\
\hline
\end{tabular}

Note: CD, consolidated drained; BAES, back analysis for effective stress; BATS, back analysis for total stress; CUD, consolidated undrained; CUDD, consolidated undrained direct; FOS, factor of safety; UUD, unconsolidated undrained; UUDD, unconsolidated undrained direct.

of remaining slope 1 where a second slide would subsequently occur.

We then carried out a similar stability assessment for remaining slope 1. The variations of the local minimum FOS values with horizontal distance from the dam centre for the eight shear strength sets are plotted in Fig. $5 b$. The digital data are summarized in Table 4. The critical slip surfaces determined by the total stress approach in association with the field vane shear strength are also plotted in Fig. 5a. From the results presented in Figs. $5 a$ and $5 b$ and Table 4, we have observations and findings similar to those obtained for the original dredged slope above. The following points should be noted:

(i) The local minimum FOS values show a pattern of variation with horizontal distance that is similar to those observed in Fig. $4 b$ for the original slope before the landslide. In general, the local minimum FOS values decrease with an increase in the horizontal distance initially, reach the global minimum at a horizontal distance of about $31 \mathrm{~m}$ from the dam centre, and then increase with a further increase of horizontal distance.

(ii) The amounts of the initial decreases in FOS values as the horizontal distance increases are small. The local minimum FOS values at horizontal distances of $16.3 \mathrm{~m}$ to $31.0 \mathrm{~m}$ are close to the corresponding global minimum values. The global minimum FOS values are less than those for the original dredged slope.

(iii) The FOS values associated with back-calculated total or effective shear strengths are much lower than the corresponding values for the original dredged slope before the first slide occurred.

The above stability assessment results also indicate that the first slide made the soft soil slope steeper in geometry. As the steeper slope had lower FOS values, it would be much easier for tension cracks and for a slide in the soil mass to occur behind the new slope crest. The area of the slipped soil mass on the cross section is estimated to be less than that associated with the first slide. Similarly, the unsta- ble zone would have also extended laterally into the reclaimed land (as shown in Fig. 1).

\section{Analysis of the subsequent slides}

As in the determination of the profile for remaining slope 1 after the first slide occurred, we can determine the remaining slope profile after the second slide occurred and then carried out the stability analysis for the remaining slope. The results are summarized in Figs. $6 a$ and $6 b$ and Table 5 . The back-scar crest after the second slide is estimated to be at a horizontal distance of $31 \mathrm{~m}$ from the dam centre.

Similarly, we determined the remaining slope profile after each of the sequential slides and carried out stability analysis for the slopes that remained. The results for remaining slope 3 after the third slide are summarized in Figs. $7 a$ and $7 b$ and Table 6 . The back-scar crest after the third slide is estimated to be at a horizontal distance of $40 \mathrm{~m}$ from the dam centre. The results for remaining slope 4 after the fourth slide are summarized in Figs. $8 a$ and $8 b$ and Table 7. The back-scar crest after the fourth slide is estimated to be at a horizontal distance of $50 \mathrm{~m}$ from the dam centre. Likewise, the back-scar crest after the fifth slide is estimated to be at a horizontal distance of $60 \mathrm{~m}$ from the dam centre.

From the results presented in Figs. $6 a-8 b$ and Tables 5-7, we can make the following important observations:

(i) The initial increases in the local minimum FOS values diminish as the distance from the dam centre increases. The remaining slopes within $10 \mathrm{~m}$ of the back-scar crests become more and more unstable with the further occurrence of retrogressive slides. The critical slip surface with global minimum FOS values are located at distances that are closer and closer to the back-scar crests.

(ii) The unstable zones with local minimum FOS values of less than unity, based on the vane shear strength, become smaller and smaller with the further occurrence of the retrogressive slides. 


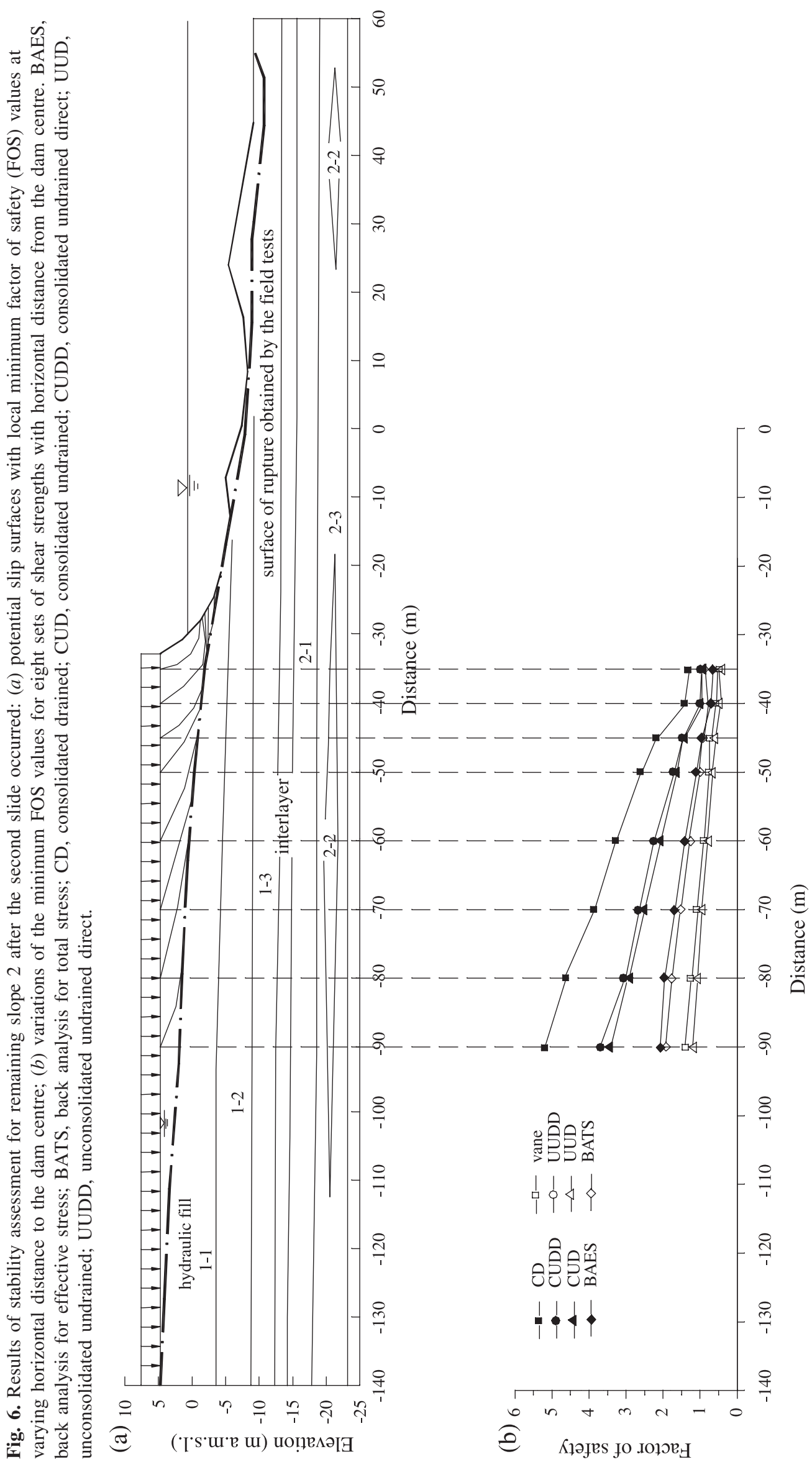


Table 5. Minimum FOS for local critical slip surfaces with varying horizontal distance from the dam centre, for remaining slope 2 after the second slide.

\begin{tabular}{|c|c|c|c|c|c|c|c|c|}
\hline \multirow{3}{*}{$\begin{array}{l}\text { Horizontal distance } \\
\text { from dam centre }(\mathrm{m})\end{array}$} & \multicolumn{8}{|c|}{ Minimum FOS with eight sets of shear strength values } \\
\hline & \multicolumn{4}{|c|}{ Effective stress approach } & \multicolumn{4}{|c|}{ Total stress approach } \\
\hline & $\mathrm{CD}$ & CUDD & CUD & BAES & UUD & UUDD & Vane & BATS \\
\hline 35 & 1.30 & 0.95 & 0.90 & 0.62 & 0.42 & 0.45 & 0.54 & 0.87 \\
\hline 40 & 1.42 & 0.99 & 0.98 & 0.70 & 0.45 & 0.46 & 0.55 & 0.78 \\
\hline 45 & 2.19 & 1.47 & 1.45 & 0.94 & 0.61 & 0.61 & 0.68 & 0.96 \\
\hline 50 & 2.59 & 1.69 & 1.66 & 1.10 & 0.67 & 0.69 & 0.74 & 1.05 \\
\hline 60 & 3.26 & 2.22 & 2.09 & 1.40 & 0.82 & 0.83 & 0.89 & 1.30 \\
\hline 70 & 3.87 & 2.63 & 2.55 & 1.68 & 0.94 & 0.96 & 1.01 & 1.51 \\
\hline 80 & 4.65 & 3.03 & 2.96 & 1.94 & 1.08 & 1.10 & 1.20 & 1.75 \\
\hline 90 & 5.21 & 3.66 & 3.44 & 2.11 & 1.18 & 1.21 & 1.36 & 1.95 \\
\hline
\end{tabular}

Note: CD, consolidated drained; BAES, back analysis for effective stress; BATS, back analysis for total stress; CUD, consolidated undrained; CUDD, consolidated undrained direct; FOS, factor of safety; UUD, unconsolidated undrained; UUDD, unconsolidated undrained direct.

(iii) The local minimum FOS values increase after the second and third retrogressive slides.

\section{Summary of the analytical study}

The variations of the local minimum FOS values with horizontal distance from the dam centre for the original cut slope and remaining slopes 1-4 are summarized in Fig. 9 (only those results associated with the undrained shear strength values from field vane tests are plotted). From Fig. 9, we can observe the change patterns of the local minimum FOS values during the occurrence of retrogressive slope failure. Such changes in the FOS values show that the soil mass immediately behind each of the back-scar crests is continuously unstable, and the soil mass of the remaining slope is becoming more and more stable after each occurrence of retrogressive slide.

The locally unstable soil mass could cause the continuous occurrence of retrogressive failure extension into the reclaimed land. However, the retrogressive extension would result in increased slope stability for the remaining soil mass with time. Consequently, the retrogressive failure extension would become smaller and smaller, as well as shallower and shallower, until the local instability of the soil mass vanished. It should be further noted that the slip surfaces of the first, second, third, fourth, and fifth slides generally follow the rupture surface that was determined from the field investigation (Fig. 8). The lateral spreading of the retrogressive slides is represented by the slide crests shown in Fig. 1.

Besides the above observations, we have found that the local minimum FOS values for each of the three pairs of shear strength values (i.e., CUDD and CUD; UUDD and UUD; and BAES and BATS) are close to each other, as shown in Figs. $4 b$ and $5 b$. It is important to note that the BAES and BATS results are very close to each other. This finding may indicate that the effective and total stress approaches could give the same result for slope stability assessment if the effective and total shear strength values are correctly determined.

The above stability assessment shows that the newly dredged slope would have a global minimum FOS value of 0.76 , on the basis of field vane shear strength. This global minimum FOS value is much greater than those of the remaining slopes after the occurrence of each of the retrogressive failure extensions. The global minimum FOS values of the remaining slopes were between 0.5 and 0.6 . The newly dredged slope was stable for about 1 month. The remaining slopes failed retrogressively within $1 \mathrm{~h}$. Therefore, it could be argued that the newly dredged slope was only marginally stable and could fail at any time. Stability assessment results from using back-calculated shear strengths also seem to support this finding.

\section{Causes of the landslide}

On the basis of the above analytical study, it can be concluded that the present slope failure with retrogressive extension was mainly caused by dredging to form a deep and steep cut slope in the underconsolidated soft marine mud. In addition, the following factors might have contributed to the landslide:

(i) backfilling with general soil fill, the sand cushion layer, and the $1.0 \mathrm{~m}$ thick temporary road over the hydraulic fill;

(ii) additional dredging in the lower portion of the newly cut slope;

(iii) pile driving; and

(iv) lowering of the tidal level before and during the retrogressive sliding.

\section{Backfilling on hydraulic fill}

As discussed in the companion paper (Li et al. 2005), backfilling with a $2.45 \mathrm{~m}$ thick general soil and a $0.4 \mathrm{~m}$ thick sand cushion was undertaken immediately before the dredge excavation to form the cut slope. The backfilling was for the application of vacuum preloading to strengthen the hydraulic fill and the recent marine mud. The general soil fill had a unit weight of $18 \mathrm{kN} / \mathrm{m}^{3}$. The sand cushion had a unit weight of $16 \mathrm{kN} / \mathrm{m}^{3}$. The general fill and sand were not compacted and thus had low shear strength values. Therefore, the backfilling with general fill and sand cushion can be considered a surcharge of $50.5 \mathrm{kPa}$ on the hydraulic fill of the reclaimed land (see Figs. 3-8). 


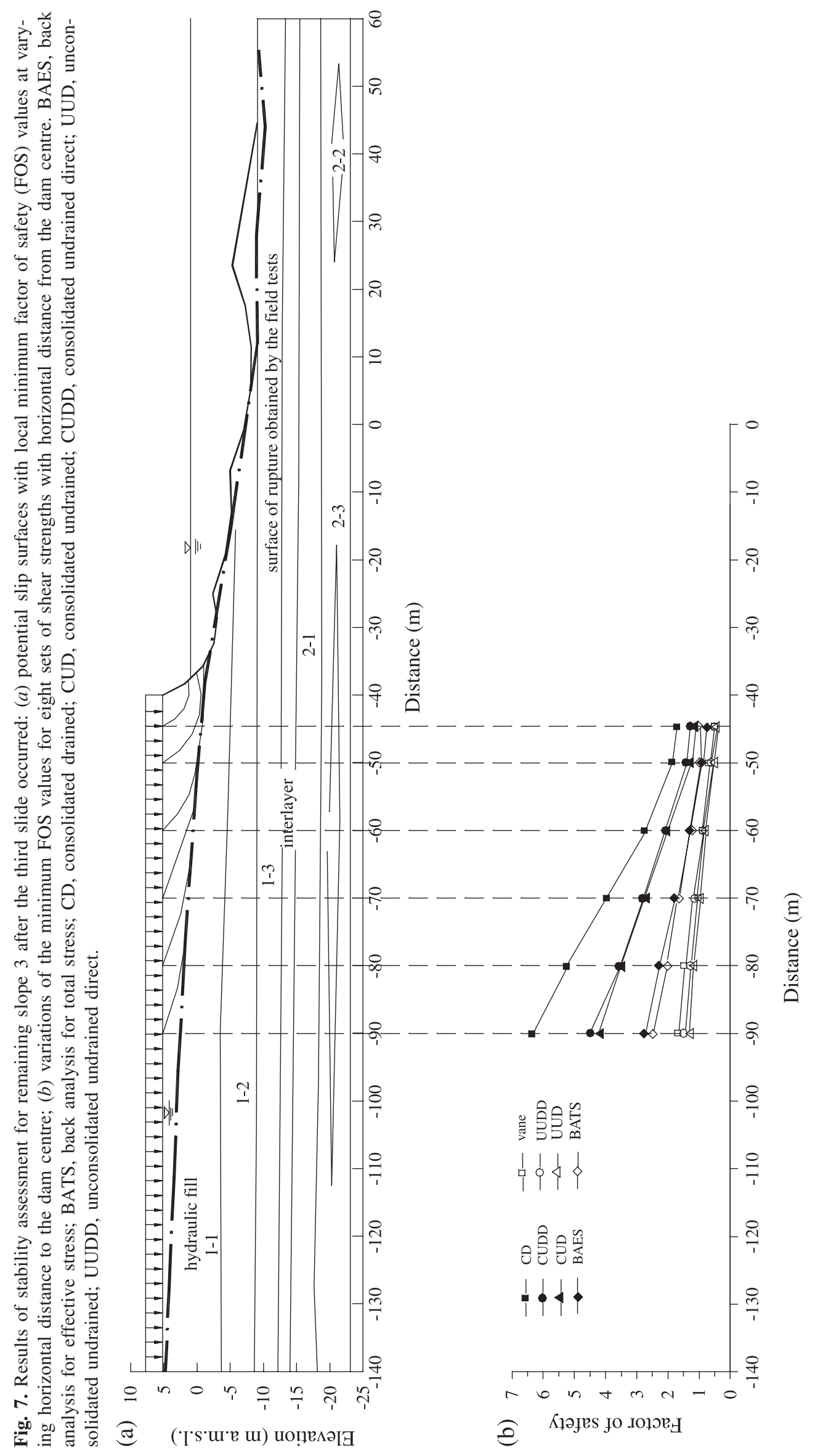


Table 6. Minimum FOS for local critical slip surfaces with varying horizontal distance from the dam centre, for remaining slope 3 after the third slide.

\begin{tabular}{|c|c|c|c|c|c|c|c|c|}
\hline \multirow{3}{*}{$\begin{array}{l}\text { Horizontal distance } \\
\text { from dam centre }(\mathrm{m})\end{array}$} & \multicolumn{8}{|c|}{ Minimum FOS with eight sets of shear strength values } \\
\hline & \multicolumn{4}{|c|}{ Effective stress approach } & \multicolumn{4}{|c|}{ Total stress approach } \\
\hline & $\mathrm{CD}$ & CUDD & CUD & BAES & UUD & UUDD & Vane & BATS \\
\hline 45 & 1.70 & 1.30 & 1.12 & 0.74 & 0.43 & 0.43 & 0.50 & 0.98 \\
\hline 50 & 1.85 & 1.34 & 1.25 & 0.85 & 0.50 & 0.54 & 0.56 & 0.95 \\
\hline 60 & 2.73 & 2.05 & 2.04 & 1.28 & 0.78 & 0.80 & 0.91 & 1.27 \\
\hline 70 & 3.98 & 2.71 & 2.80 & 1.77 & 0.97 & 1.05 & 1.15 & 1.67 \\
\hline 80 & 5.21 & 3.55 & 3.50 & 2.26 & 1.18 & 1.25 & 1.45 & 2.04 \\
\hline 90 & 6.35 & 4.49 & 4.19 & 2.70 & 1.31 & 1.46 & 1.63 & 2.48 \\
\hline
\end{tabular}

Note: CD, consolidated drained; BAES, back analysis for effective stress; BATS, back analysis for total stress; CUD, consolidated undrained; CUDD, consolidated undrained direct; FOS, factor of safety; UUD, unconsolidated undrained; UUDD, unconsolidated undrained direct.

The temporary road, formed of residual soil placed at a thickness of $1 \mathrm{~m}$, was constructed between 28 August and 4 September 1997, when the dredged slope profile was modified. The temporary road was located immediately behind the dam and caused a surcharge of $17 \mathrm{kPa}$ over a $5 \mathrm{~m}$ wide strip on the hydraulic fill (see Figs. 3 and 4). This additional fill would also have some effect in reducing dredged slope stability.

The stability assessment presented in Fig. 4 has incorporated the effect of the above surcharge. Using the total stress approach in association with undrained shear strength (field vane) values, we have found that the global minimum FOS values would be equal to 0.76 and 1.05 for the newly cut slope with and without the backfilling surcharge, respectively. The stability assessment results thus indicate that backfilling was a main factor in rendering the dredged slope marginally stable.

\section{Additional dredge excavation}

The cut slope was formed by dredging between 25 July and 13 August 1997. The profile of the cut slope was further dredged to accommodate the barge for pile driving between 28 August and 4 September 1997. This additional dredge excavation resulted in the low portion of the cut slope having a steeper slope angle than in the original design (see Figs. 24). Thirteen days after this profile modification, the landslide occurred. Using the total stress approach in association with undrained shear strength (field vane) values, we found that the global minimum FOS values would be equal to 0.76 and 0.88 for the newly cut slope with and without the profile modification, respectively. The stability assessment results thus indicate that the additional dredge excavation would have rendered the dredged slope marginally unstable.

\section{Pile driving}

The installation of the driven piles commenced immediately after the completion of the additional dredging. Between 5 and 15 September 1997, fifty-five piles were driven into the western portion of the dredged slope (Fig. 1). The driven piles were made of reinforced concrete and had a square cross section of $0.55 \mathrm{~m} \times 0.55 \mathrm{~m}$ or $0.65 \mathrm{~m} \times 0.65 \mathrm{~m}$. The piles were driven into the silt sand layer at $22.5-27 \mathrm{~m}$ below standard sea level. Pile driving was not carried out on 15 September 2002. The landslide occurred on the morning of the next day.

The fact that pile driving could cause slope instability has previously been reported by D'Appolonia (1971), Massarsch and Broms (1981), and Anderson et al. (1992). Slope instability during pile driving is due to soil displacement by the pile, generation of excess porewater pressure, and ground vibration. In cohesive soils, generation of excess porewater pressure is usually within a zone that is four times the pile diameter (Massarsch and Broms 1981).

In the present case, the first slide occurred in the middle of the dredged slope and at a distance of greater than $30 \mathrm{~m}$ from the driven piles (Fig. 1). Therefore, the effect of pile driving on the generation of porewater pressure in the centre portion of the dredged slope might have been limited. Pile driving was not carried out when the slope failed. Hence, there was no effect of ground vibration on the landslide. However, the direction of the pile driving was toward that of the first slide. The silty sand seams and lenses possibly present in the dredged slope could have become pipes or channels, allowing soil and water to flow into the area where the first landslide occurred. As a result, soil displacement by piles could have had a significant effect on the first slide and deserves further investigation. Furthermore, the topographical survey results from before and after the landslide have shown that the installed piles might have offered some stabilization to the western portion of the dredged slope ( $\mathrm{Li}$ et al. 2005).

\section{Lowering of the tidal level during retrogressive sliding}

The tide in Xingang Harbor in the irregular semidiurnal category. According to the information available, the tidal level fell from $+4.11 \mathrm{~m}$ a.m.s.l. at 03:00 to $+0.99 \mathrm{~m}$ a.m.s.l. at 09:00, when the landslide occurred. The tide reached its lowest level of $+0.65 \mathrm{~m}$ a.m.s.l. at about 10:00 on the morning of the landslide. The seawater level was drawn down by about 3-4 $\mathrm{m}$ before and during the retrogressive slope failure. Such drawdown of the seawater level could have triggered the slope failure (Morgenstern 1963), although the tidal level rose and fell daily before the day of the landslide. The fall of the tidal level between 03:00 and 10:00 should 


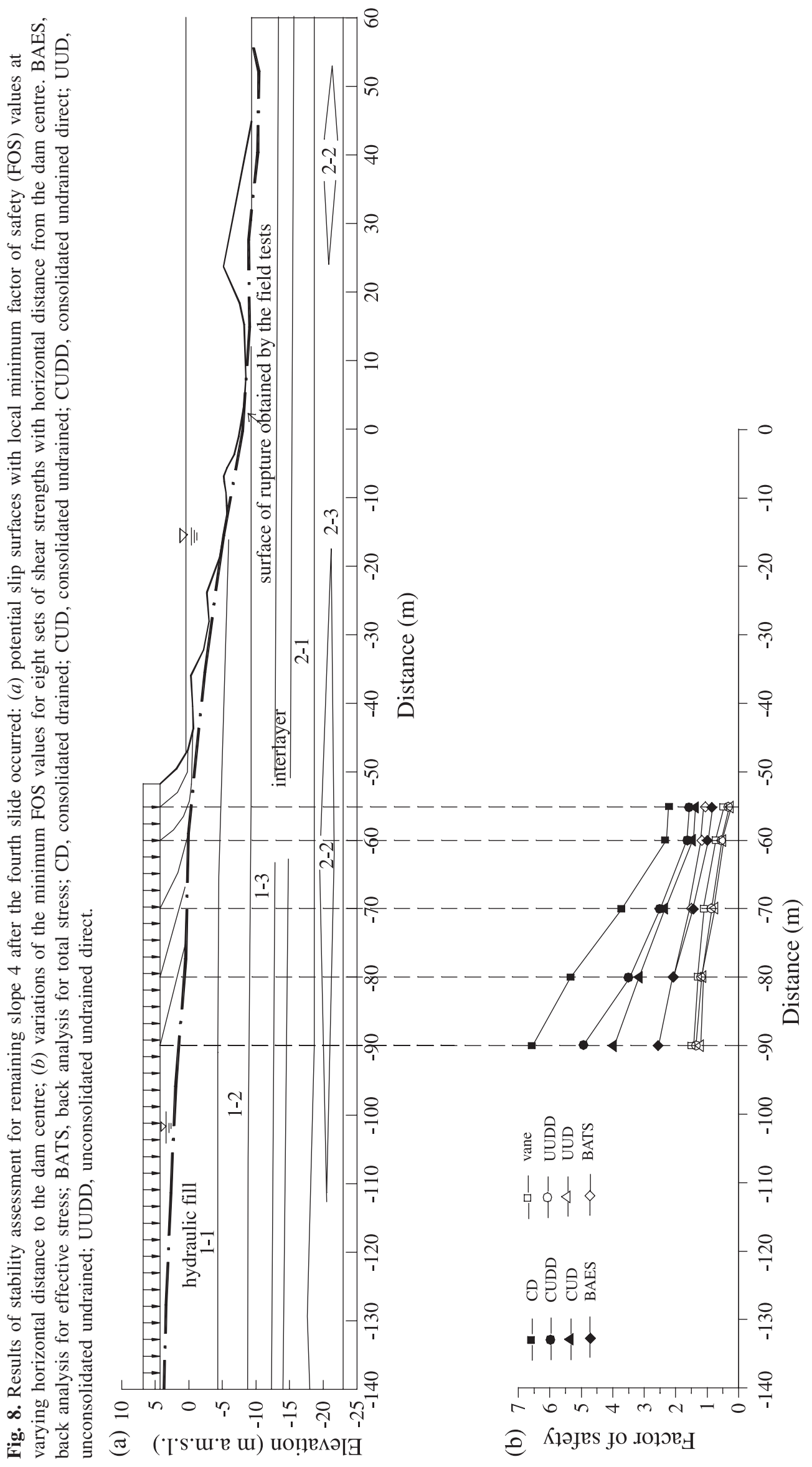


Table 7. Minimum FOS for local critical slip surfaces with varying horizontal distance from the dam centre, for remaining slope 4 after the fourth slide.

\begin{tabular}{|c|c|c|c|c|c|c|c|c|}
\hline \multirow{3}{*}{$\begin{array}{l}\text { Horizontal distance } \\
\text { from dam centre }(\mathrm{m})\end{array}$} & \multicolumn{8}{|c|}{ Minimum FOS with eight sets of shear strength values } \\
\hline & \multicolumn{4}{|c|}{ Effective stress approach } & \multicolumn{4}{|c|}{ Total stress approach } \\
\hline & $\mathrm{CD}$ & CUDD & CUD & BAES & UUD & UUDD & Vane & BATS \\
\hline 55 & 2.38 & 1.70 & 1.46 & 0.88 & 0.41 & 0.46 & 0.60 & 1.18 \\
\hline 60 & 2.48 & 1.72 & 1.51 & 1.01 & 0.64 & 0.68 & 0.80 & 1.25 \\
\hline 70 & 3.80 & 2.62 & 2.42 & 1.56 & 0.90 & 0.93 & 1.12 & 1.69 \\
\hline 80 & 5.28 & 3.54 & 3.29 & 2.14 & 1.21 & 1.26 & 1.40 & 2.12 \\
\hline 90 & 6.49 & 4.94 & 4.01 & 2.71 & 1.36 & 1.53 & 1.66 & 2.71 \\
\hline
\end{tabular}

Note: CD, consolidated drained; BAES, back analysis for effective stress; BATS, back analysis for total stress; CUD, consolidated undrained; CUDD, consolidated undrained direct; FOS, factor of safety; UUD, unconsolidated undrained; UUDD, unconsolidated undrained direct.

Fig. 9. Variations of the minimum factor of safety values with the horizontal distance to the dam centre by the total stress approach with the field vane shear strength values.

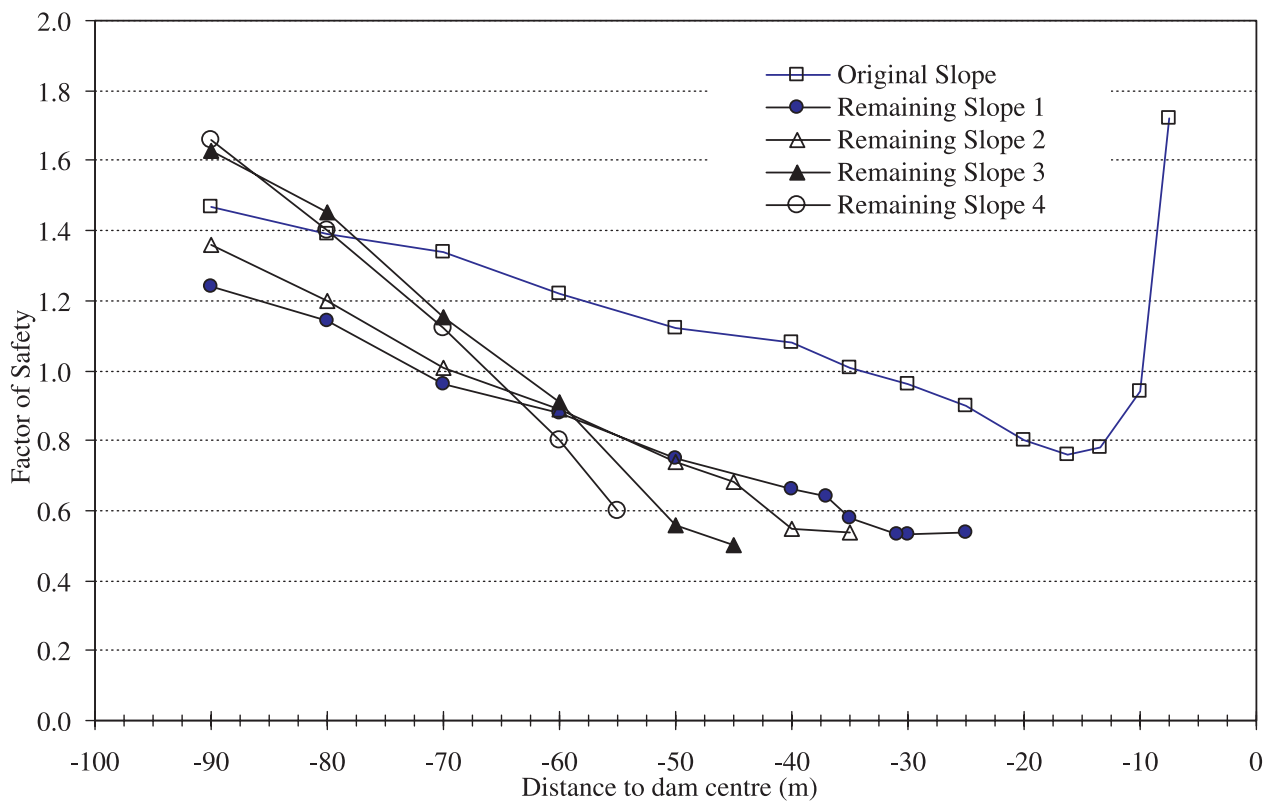

have had a triggering effect on the occurrence of the present landslide.

\section{Engineering approach to retrogressive landslide studies}

In the above, we have presented an engineering approach to the analysis of a major slope failure with retrogressive extension into recently reclaimed land. This approach can be used to explicitly determine the most critical slip surface in either the dredged slope or each of the remaining slopes in the process of retrogressive failure extension. This most critical slip surface is associated with the global minimum FOS value, which is determined from the variation of local minimum FOS with horizontal distance to the slope crest. The classical Bishop method of slices was used for the FOS calculations. Using this approach, we can examine the extent of the first slide, the second slide, the third slide, the fourth slide, and so on, until the remaining slope becomes stable. The basal surfaces of the retrogressive slides together form a common surface. This "predicted" basal surface is found to be very close to the rupture surface determined in the field investigation. In conjunction with this engineering approach, we have used eight sets of undrained and drained shear strength values and both the total and the effective stress approaches. The eight sets of undrained and drained shear strength values are those determined in the undrained direct shear tests with or without initial consolidation, the triaxial tests with or without initial consolidation and drainage, the field vane tests, and the back analysis method. The slope stability assessment reveals that the variations of minimum FOS values with horizontal distance to the slope crest have similar patterns, although their absolute values are different. In general, the effective stress approach gives higher FOS values than the total stress approach. The total stress approach with the undrained shear strength from field vane tests gives the best results for analysis of the present retrogressive landslide.

The minimum FOS values computed indicate that the dredged slope comprising underconsolidated marine mud 
was only marginally stable. The computed minimum FOS value is as low as $0.7-0.8$, on the basis of the average field vane strength values. However, if we had used the upper limit of the field vane strength values measured, the minimum FOS value for the dredged slope would have been close to unity.

\section{Concluding remarks}

In this paper and the companion one ( $\mathrm{Li}$ et al. 2005), we have presented a field investigation and analysis of a major landslide that occurred in a dredged slope comprising underconsolidated soft soils. The study has provided good explanations of the kinematic movement and mechanism of the regressive landslide with lateral spreading.

The first slide in the dredged slope is believed to have caused an initial decrease in the FOS for the remaining slope. It occurred after tension cracks developed in the dam. Further retrogressive failure of the reclaimed land then caused an increase in the FOS for the remaining slope. After several retrogressive slides, the remaining slope would eventually become stable, and the process of retrogressive failure extension into the reclaimed land would stop. Among the eight sets of undrained and drained shear strength values, the undrained shear strength values from field vane tests in association with the total stress approach resulted in the best explanation of the retrogressive landslide. In particular, the problem of unknown actual pore pressure levels in the underconsolidated soils can be accommodated with the total stress approach associated with undrained shear strength (field vane). The other seven sets of the shear strength values can also give a reasonably good explanation of the process of retrogressive slope failures. These results indicate that the proposed approach can therefore be applied to the explanation or prediction of similar cases of retrogressive landslide.

It has been found that the dredge excavation of the underconsolidated marine mud was the main cause for the landslide. The placement of a thick general fill and sand cushion prior to vacuum preloading was another important factor that rendered all of the reclaimed land unstable. The fills in effect constituted a heavy surcharge on the saturated hydraulic fill and recent marine mud. The landslide would not have happened if vacuum preloading had been carried out and completed before the dredge excavation. Vacuum consolidation would have resulted in a significant increase in the shear strength values of the hydraulic fill and marine mud for subsequent stages of port construction. The stability assessment with the effective stress approach associated with drained shear strength values demonstrated that the original dredged slope would have had the FOS values in Table 3 greater than unity if the soils had had the drained shear strength values listed in Table 1.

\section{Acknowledgements}

The authors would like to acknowledge the financial support from the Research Grants Council of Hong Kong Special Administrative Region of the People's Republic of China and the Hong Kong Jockey Club Charities Trust. The authors thank the editor, Professor A.J. Valsangkar, the associate editor, and two peer reviewers for their valuable com- ments and suggestions, which enhanced the presentation of the paper.

\section{References}

Anderson, D.G., Riker, R.E., and Erickson, B.P. 1992. Pile-driving: Can it cause slope movement? In Proceedings of the Conference of Ports, Committee of Ports, Coastal and Ocean Engineering Division of the ASCE and U.S. Section of the Navigation Congress, Seattle, Wash., 20-22 July 1992. Vol. 1, pp. 350-363.

Arai, K., and Tagyo, K. 1985. Determination of noncircular slip surface giving the minimum factor of safety in slope stability analysis. Soils and Foundations, 25: 43-51.

Baker, R. 1980. Determination of the critical slip surface in slope stability computations. International Journal for Numerical and Analytical Methods in Geomechanics, 4: 333-359.

Bishop, A.W. 1955. The use of the slip circle in the stability analysis of slopes. Géotechnique, 5: 7-17.

Boutrup, E., and Lovell, C.W. 1980. Search techniques in slope stability analysis. Engineering Geology, 16: 51-61.

Broms, B.B., and Wong, K.S. 1991. Landslides. In Foundation engineering handbook. 2nd ed. Edited by H.Y. Fang. Kluwer Academic, London, U.K. pp. 410-435.

BSI. 1988. Design of quay walls, jetties and dolphins (BS6349Part 2: 1988). British Standards Institution (BSI), London, U.K.

BSI. 2000. Maritime structures. Part I: Code of practice for general criteria (BS6349-Part 1: 2000). British Standards Institution (BSI), London, U.K.

Carson, M.A., and Lajoie, G. 1981. Some constraints on the severity of landslide penetration in sensitive deposits. Géographie physique et Quaternaire, 35: 301-316.

CEO. 2002. Port works manual - design, construction and maintenance. Civil Engineering Office (CEO), Department of Civil Engineering, Government of Hong Kong, Hong Kong.

Chen, Z.-Y., and Shao, C.-M. 1988. Evaluation of minimum factor of safety in slope stability analysis. Canadian Geotechnical Journal, 25: 735-748.

Ching, R.K.H., and Fredlund, D.G. 1983. Some difficulties associated with the limit equilibrium method of slices. Canadian Geotechnical Journal, 20: 661-672.

D'Appolonia, D.J. 1971. Effects of foundation construction on nearby structures. In Proceedings of the 4th Panamerican Conference on Soil Mechanics and Foundation Engineering, San Juan, Puerto Rico. Vol. 1, pp. 189-236.

Duncan, J.M. 1996. State of the art: limit equilibrium and finiteelement analysis of slopes. Journal of Geotechnical Engineering, ASCE, 122: 577-596.

Endicott, J. 2001. Drained reclamation in Hong Kong. In Proceedings of the 3rd International Conference on Soft Soil Engineering, 6-8 December 2001, Hong Kong. Edited by C.F. Lee, C.K. Lau, C.W.W. Ng, A.K.L. Kwong, P.L.R. Pang, J.-H. Yin, and Z.Q. Yue. A.A. Balkema Publishers, Tokyo. pp. 3-11.

Fang, H.Y., and Mikroudis, G.K. 1991. Stability of earth slopes. In Foundation engineering handbook. 2nd ed. Edited by H.Y. Fang. Kluwer Academic Publishers, London, U.K. pp. 379-409.

Fredlund, D.G., and Krahn, J. 1977. Comparison of slope stability methods of analysis. Canadian Geotechnical Journal, 14: 429_ 439.

GCO. 1984a. Investigation of a failure at Junk Bay controlled tip. Geotechnical Control Office (GCO), Engineering Development Department, Government of Hong Kong, Hong Kong. Advisory Report ADR 17/84. 
GCO. 1984b. Geotechnical manual for slopes. Geotechnical Control Office (GCO), Engineering Development Department, Government of Hong Kong, Hong Kong.

Greco, V.R. 1996. Efficient Monte Carlo technique for locating critical slip surface. Journal of Geotechnical Engineering, ASCE, 122: 517-525.

Hou, Z. (Editor). 1987. Tianjin soft soil foundations. Tianjin Science \& Technology Press, Tianjin, China. [In Chinese.]

Huang, Y.H. 1983. Stability analysis of earth slopes. Van Nostrand Reinhold Co., New York.

Janbu, N. 1977. Slopes and excavations in normally and lightly overconsolidated clays. In Proceedings of the 9th International Conference on Soil Mechanics and Foundation Engineering, Tokyo. Vol. 2, pp. 549-566.

Lacasse, S. 2001. Parameters for soft clays. In Proceedings of the 3rd International Conference on Soft Soil Engineering, 6-8 December 2001, Hong Kong. Edited by C.F. Lee, C.K. Lau, C.W.W. Ng, A.K.L. Kwong, P.L.R. Pang, J.-H. Yin, and Z.Q. Yue. A.A. Balkema Publishers, Tokyo. pp. 25-36.

Lam, B.M.T., and Leung, B.N. 1992. Ma On Shan area 77, reclamation failure. In Proceedings of the Seminar on Sha Tin New Town Development. Hong Kong, November, Hong Kong Institution of Engineers. pp. 85-100.

Lee, C.F., Lau, C.K., Ng, C.W.W., Kwong, A.K.L., Pang, P.L.R., Yin, J.-H., and Yue, Z.Q. (Editors). 2001. Proceedings of the 3rd International Conference on Soft Soil Engineering, 6-8 December 2001, Hong Kong. A.A. Balkema Publishers, Tokyo.

Lefebvre, G. 1981. Strength and slope stability in Canadian soft clay deposits. Canadian Geotechnical Journal, 18: 420-442.

Li, S., Yue, Z.Q., Tham, L.G., Lee, C.F., and Yan, S.W. 2005. Slope failure in underconsolidated soft soils during the development of a port in Tianjin, China. Part 1: Field investigation. Canadian Geotechnical Journal, 42. This issue.

Massarsch, R.K., and Broms, B.B. 1981. Pile driving in clay slopes. In Proceedings of the 10th International Conference on Soil Mechanics and Foundation Engineering, Stockholm, Sweden, 15-19 June. A.A. Balkema, Rotterdam, The Netherlands. Vol. 3, pp. 469-474.

Morgenstern, N. 1963. Stability charts for earth slopes during rapid drawdown. Géotechnique, 13: 121-131.
Morgenstern, N.R., and Price, V.E. 1965. The analysis of the stability of general slip surfaces. Géotechnique, 15: 79-93.

NHRI. 1999. National standards of soil test methods (GB/T 501231999). Nanjing Hydraulic Research Institute (NHRI), Ministry of Construction of China, Planning Publishing House, Beijing, China. [In Chinese.]

Nguyen, V.U. 1985. Determination of critical slope failure surfaces. Journal of Geotechnical Engineering, ASCE, 111: 238250.

Rahardjo, H., and Fredlund, D.G. 1984. General limit equilibrium method for lateral earth force. Canadian Geotechnical Journal, 21: $166-175$.

Roy, M., and Leblanc, A. 1988. Factors affecting the measurements and interpretation of the vane strength in soft sensitive clays. In Vane shear strength testing in soils: field and laboratory studies. Edited by A.F. Richards. American Society for Testing and Materials, Philadelphia, Pa. ASTM Special Technical Publication 1014, pp. 117-128.

Sheng, Q., Yue, Z.Q., Lee, C.F., Tham, L.G., and Zhou, H. 2002. Estimating the excavation disturbed zone in the permanent shiplock slopes of the Three Gorges Project, China. International Journal of Rock Mechanics and Mining Sciences, 39: 165-184.

Skempton, A.W. 1977. Slope stability of cuttings in London clay. In Proceedings of the 9th International Conference on Soil Mechanics and Foundation Engineering. Tokyo. Vol. 3, pp. 261270.

Spencer, E. 1973. Thrust line criterion in embankment stability analysis. Géotechnique, 23: 85-100.

Tsinker, G.P. 1997. Handbook of port and harbour engineering: geotechnical and structural aspects. Chapman \& Hall, London, U.K.

Yue, Z.Q., and Lee, C.F. 2002. A plane slide that occurred during construction of a national expressway in Chongqing, southwestern China. Quarterly Journal of Engineering Geology and Hydrogeology, 35: 309-316.

Zou, J.-Z., Williams, D.J., and Xiong, W.-L. 1995. Search for critical slip surfaces based on finite element method. Canadian Geotechnical Journal, 32: 233-246. 